\title{
Flagelo branco, de Athena Farrokhzad: Poesia e exílio
}

\author{
Elizabeth Ramos ${ }^{1}$ \\ Juliana Porsani Jarkvist ${ }^{2}$ \\ "O escritor ergue uma casa [...]. Para um homem \\ que não tem mais uma terra natal, escrever torna- \\ -se um lugar para viver [...]." \\ T. Adorno \\ apud Edward Said
}

A irano-sueca Athena Farrokhzad nasceu em Teerã, em 1983, de onde, ainda criança, fugiu com a família para a Suécia. Cresceu em Gotemburgo e hoje vive em Estocolmo, atuando como poeta, tradutora e professora na escola de criação literária de Biskops-Arnö. Seu posicionamento feminista é percebido pelas alas mais conservadoras do país como radical.

1 Mestre e Doutora em Letras e Linguística pela Universidade Federal da Bahia (1999 e 2003, respectivamente), onde é Professora Associadoa II no Departamento de Letras Germânicas e no Programa de Pós-Graduação em Literatura e Cultura. Em março de 2014, concluiu estágio de pós-doutorado na Universidade de São Paulo (USP), onde desenvolveu pesquisa sobre a tradução da obscenidade na comédia shakespeariana. É pesquisadora no campo dos Estudos Shakespearianos e da Tradução (literária e intersemiótica). Nessas áreas, orienta alunos de iniciação científica, mestrado e doutorado.

2 Doutoranda na Universidade de Södertörn (Suécia), onde desenvolve pesquisa sobre dinâmicas de desenvolvimento rural, gênero e adaptações em modos de vida em Moçambique. Mestre em Geografia Humana (Universidade de Estocolmo) e Bacharel em Relações Internacionais pela UNESP. 
Parece apropriado que aqueles que criam arte numa civilização de quase barbárie, que produziu tanta gente sem lar, sejam eles mesmos poetas sem casa e errantes entre as línguas. Excêntricos, arredios, nostálgicos, deliberadamente inoportunos. (George STEINER, apud SAID, 2003, p. 47)

Em 2013, Farrokhzad trouxe a público o longo poema de sua autoria - Vitsvit- encenado no palco, aclamado pela crítica e pelos leitores mais progressistas, e também indicado para vários prêmios, inclusive o destacado Augustpriset. Ainda desconhecido do leitor brasileiro, o poema foi traduzido para o inglês por Jennifer Hayashida sob o título White Blight ("Praga branca").

Os versos escritos em sueco remetem à dor do processo migratório forçado pela guerra e às marcas deixadas nos membros da família, fazendo emergir, ainda, reflexões acerca do racismo. Na sua construção poética, além do eu lírico, cinco vozes emergem - a mãe otimista, o pai idealista-marxista, o irmão amante de tecnologias, a avó pragmática e o tio - talvez como uma forma de contornar o impedimento revelado por Edward Said no ensaio 'Entre mundos': “' [...] meu sentimento de dúvida e de deslocamento, de sempre me sentir no lado errado, em um lugar que parecia me escapar assim que eu tentava defini-lo ou descrevê-lo" (SAID, 2003, p. 305).

Assim, na voz dos familiares, a poeta retoma o passado, os horrores por eles sofridos durante a guerra e a alienação diante da nova cultura, cujo acolhimento não apaga o profundo estranhamento diante do desconhecido, construindo uma colagem de diferentes pontos de vista a partir das linhas linguística, cultural, racial e étnica que separam o mundo do refugiado daquele do "dono da casa". Em apenas duas das páginas de um poema que se estende num volume de setenta páginas o eu lírico se coloca diretamente para o leitor.

Cada uma das vozes é apresentada de forma concisa e precisa, enfatizada pelas repetições ("minha mãe disse...", "meu pai disse...", “meu tio disse...”), que reforçam o aspecto contundente do poema como pancadas de um martelo e assim fazem reverberar as experiências de sujeitos afastados da cultura em que nasceram, da língua e do lar que perderam. A experiência da guerra no Irã, o contexto da imigração e a vida no exílio afetam diferentemente cada membro da família, sua relação mútua e com o mundo ao redor. $\mathrm{O}$ passado, claramente, segue assombrando o presente com sua violência.

Há experiências sobre as quais não posso escrever aqui. Experiências que revelam violência patriarcal, numa esfera íntima, que me parecem impossíveis de serem descritas a uma audiência predominantemente branca, 
pois meu agressor se parece comigo. (Farrokhzad, artigo no jornal sueco Aftonbladet, 22/01/2014)

Dessa forma, as experiências que Farrokhzad escolheu para compartilhar constroem o poema e revelam a heterogeneidade extrema e a natureza cambiante da vivência do refugiado, impossível de ser descrita em termos precisos, uma vez que diferentes experiências migratórias se entrelaçam. O resultado é um texto em que a ativista política consegue tratar da desilusão do eu lírico sem cair na armadilha da ira.

Neste sentido, a experiência do refugiado é também a experiência tradutória, na medida em que se trata de um processo de natureza cambiante, migratória, resultante de um deslocamento num constante e infindável adiamento adaptativo. É portanto na différance derridiana que o rastro do processo migratório transforma-se e se suplementa.

No texto traduzido, fomos instigadas pelos rastros próprios da poesia do Oriente Médio observados num poema escrito em língua ocidental, o sueco, que traduzimos para o português do Brasil. Deparamo-nos com armadilhas culturais impostas por uma linguagem aparentemente pomposa, por vezes estranha, melodramática e com floreios em excesso quando comparada aos nossos textos literários contemporâneos. Em dado trecho do longo poema, por exemplo, o eu lírico traz a lembrança das reflexões da avó no verso: "E a mãe de minha mãe disse: Uma ferida na aurora, quando a noite insone impõe / uma escuridão que não pode ser capturada / A sensação dos céus onde descansam outras luas". No léxico, palavras como "serifa" (estrofe 3 ), embora existentes em português, não são usadas. Metáforas, que compõem praticamente todo o poema, impõem dificuldade na elucidação, dado o nosso desconhecimento de uma situação de guerra num território que não nos é familiar. Esses aspectos dificultaram ainda mais a nossa tarefa como tradutoras. No processo, para marcar a grande interseção de línguas e culturas que marcam a construção do poema, decidimos manter alguns rastros da língua sueca traduzindo, por exemplo, morbror não apenas como "tio", mas como "irmão de minha mãe" (mor = mãe / bror = irmão), e mormor ( mor = mãe / mor = mãe) como "mãe de minha mãe" em vez de simplesmente "avó", ambos antecedidos do possessivo $\mathrm{min}$ (meu/minha).

Embora as estrofes não sejam numeradas no poema de Farrokhzad, preferimos identificá-las com números no intuito de facilitar a observação das soluções tradutórias por parte do leitor. Grafamos o texto sueco em itálico e deixamos o texto traduzido em negrito. 
No quarto verso, encontramos a palavra sueca bära (estrofe 4), cujo significado é carregar ou aguentar. No entanto, como usamos a palavra "resistência" para traduzir motstånd (para a qual não há outra alternativa), preferimos combiná-la com o verbo "oferecer". Permanentas (estrofe 4): como não temos o verbo em português - do substantivo "permanente", tornar-se permanente, optamos por "encrustar".

Traduzimos o verso "Begrav mig där all egendom exproprierats" (estrofe 26) como "Enterre-me onde toda a propriedade tenha sido expropriada", optando por acrescentar "numa terra sem amos", no sentido de estabelecer uma relação intertextual com o hino da Internacional Socialista, dada a posição marxista do pai. No verso seguinte, traduzimos a palavra sötebrödsdagar (estrofe 26), composta por doce + pão + dias, como "dias felizes".

O texto traduzido, que aqui apresentamos, é, pois, apenas um fragmento do longo livro-poema Vitsvit, que traduzimos como Flagelo branco. No formato original, o aspecto visual imediatamente chama a atenção do leitor: os versos são escritos em letras brancas sobre boxes pretos, numa clara alusão a uma escrita construída sobre o luto. Ademais, são separados por amplos espaços vazios e irregulares de silêncio, possibilitando ao leitor a reflexão sobre as tensões relacionadas à "perda da relação 'natural' da cultura com os territórios geográficos e sociais e, ao mesmo tempo, certas relocalizações territoriais relativas, parciais, das velhas e novas produções simbólicas" (CANCLINI, 2008, p. 309).

O exílio nos compele estranhamente a pensar sobre ele, mas é terrível de experenciar. Ele é uma fratura incurável entre um ser humano e um lugar natal, entre o eu e seu verdadeiro lar: sua tristeza essencial jamais pode ser superada. E, embora seja verdade que a literatura e a história contêm episódios heroicos, românticos, gloriosos e até triunfais da vida de um exilado, eles não são mais do que esforços para superar a dor mutiladora da separação. As realizações do exílio são permanentemente minadas pela perda de algo deixado para trás para sempre. (SAID, 2003, p. 46)

A seguir, apresentamos nossa tradução do fragmento do poema Vitsvit, trabalho que se reveste de marcante traço intercultural em vista de ser escrito por uma poeta sueca, nascida no Irã, no seio de uma família iraniana, que migrou para a Suécia em razão dos horrores da guerra. O poema leva-nos a refletir não apenas sobre as escolhas tradutórias de ordem linguística, mas, em especial, sobre o flagelo da migração forçada pelos violentos conflitos no mundo contemporâneo. 
Min mor sa: Jag ska återta det som tillhör mig

Du ska möta döden berövad på språk

Mållös är du kommen, mållös ska du gå

Minha mãe disse: Um dia, recupero o que me pertence

Você afrontará a morte sem ter uma língua

Chegou sem falar, sem falar partirá

2

Min far sa: Jag skrev om bröd och rättvisa

och så länge den utsvultne kunde läsa

gjorde mig typsnittet detsamma

Meu pai disse: Eu escrevia sobre o pão e a justiça

Se o faminto conseguisse ler

Pouco importava a fonte da letra

3

Min far sa: Seriferna sticker $i$ mina fingrar

Meu pai disse: As serifas alfinetam-me os dedos

4

Min far sa: Hur mycket motstånd kan människofettet bära

innan piskrappen permanentas

Min far sa: Om du glömmer bort alfabetet

bittar du det på min ryggtavla

Meu pai disse: Quanta resistência pode a carne humana oferecer

Antes de o açoite nela se encrustar?

Meu pai disse: Se você esquecer o alfabeto

Poderá encontrá-lo nas minhas costas

5

Min far sa: Först när du förlåter den som angett dig vet du vad våld vill säga

Meu pai disse: Apenas quando você perdoa aquele que o delatou, poderá compreender o que é a violência

6

Min far sa: Det fanns de som avrättades i gryningen innan sömnen skingrats

Meu pai disse: Havia os que eram executados na alvorada, antes de o sono se dissipar 
7

Min mor sa: Det fanns de som fick betala för kulorna för att fä begrava sina döttrar

Minha mãe disse: Havia os que tinham que pagar pelas balas

Para que pudessem enterrar suas filhas

\section{8}

Min mor sa: In i vilken segrares natt slungade denna seger oss

Minha mãe disse: $\mathrm{Na}$ noite do vitorioso esta vitória nos lançou

9

Min far sa: Din morbror fanns med på en knastrande telefonlinje

Din morbror raffinerade sina liknelser med varje piskrapp

Meu pai disse: $\mathbf{O}$ irmão de sua mãe nos chegava entre os ruídos da linha telefônica

O irmão de sua mãe aprimorava suas fábulas a cada chiado

10

Min bror sa: Begrav mig inte här

Begrav mig där piskorna är virtuella

Meu irmão disse: Não me enterre aqui

Enterre-me onde os açoites sejam virtuais

11

Min morbror sa: Allting kommer du att glömma

utom minnet som du alltid kommer att minnas

Jag minns att innan kriget tuggade soldaten med mina tänder

Agitatorn skrek med min hals

O irmão de minha mãe disse: Tudo esquecerei

Exceto a memória, que sempre guardarei

do soldado mastigava com os meus dentes

$\mathrm{E}$ o rebelde gritava com a minha garganta

12

Min morbror sa: För mina sluttande axlars skull

för mitt ständiga leende

För denna stenhögs skull som en gång var mitt bus 
O irmão de minha mãe disse: Pelos meus ombros curvados

Pelo meu sorriso constante

Por este monte de pedras que um dia foi minha casa

13

Min morbror sa: Finns det någon pöl där kriget inte tvättat sina blodiga händer

O irmão de minha mãe disse: Existe alguma poça onde a guerra não tenha lavado suas mãos sangrentas

\section{4}

Min morbror sa: Det fanns de som avrättades $i$ varje soluppgång

Det fanns de som stannade kvar och såg domsluten verkställas

O irmão de minha mãe disse: Havia os que eram executados a cada nascer do sol

Havia os que ficavam e assistiam à execução das sentenças

\section{5}

Min mor sa: Varför åkallar de gud fràn bustaken

Har de glömt att det var gud som böll i piskan

när deras mödrar torterades

Minha mãe disse: Por que dos telhados clamam a deus

Esquecendo de que era deus quem segurava o açoite, quando suas mães eram torturadas?

16

Min mor sa: Visa mig den som bebor sitt ansikte så ska jag visa dig den som inget ansik.te förtjänar

Minha mãe disse: Mostre-me aquele que mostra a sua cara e eu lhe mostrarei aquele que não merece cara alguma

17

Min bror sa: Jag vill veta vem som förnedrades för min skull

Vilk a affiniteter jag gjort mig skyldig till

och vilk a repressalier som väntar

Meu irmão disse: Quero saber quem se humilhou por minha causa

De quem me tornei devedor

E que represálias me espreitam 
18

Min bror sa: Det finns en slakt som alltid ska pågå för ett tecken ingen kan minnas

Meu irmão disse: Há massacres que sempre ocorrerão por um símbolo de que ninguém se lembra

19

Min morbror sa: Vad ska det bli av oss sedan vi utkämpat vår befrielse med samma medel som bållit oss fänna

O irmão de minha mãe disse: $\mathbf{O}$ que será de nós depois que tivermos conquistado a liberdade

com os mesmos meios que nos mantiveram cativos

20

Min far sa: Kroppar utan klarhet, kroppar utan skugga

Meu pai disse: Corpos sem luz, corpos sem sombra

21

Min bror sa: Vanan att knäböja ska ersättas av glädjen att befalla

Meu irmão disse: $\mathrm{O}$ costume de ajoelhar-se será substituído pela alegria de comandar

22

Min far sa: Det finns ett krig som utspelar sig i innanmätet

Det finns en fiende som störtar fram ur mina bänder och läppar

Meu pai disse: Há uma guerra que se trava em minhas entranhas

Há um inimigo que se lança das minhas mãos e dos meus lábios

23

Min bror sa: Det finns en feber som eskalerar för varje slag

Det finns en maskin som hamrar $i$ avstängt läge

Meu irmão disse: Há uma febre que aumenta a cada golpe

Há u'a máquina que martela mesmo desligada

24

Min far sa: Våldet är ett språk i vilket handen excellerar

Meu pai disse: A violência é uma língua em que a mão se destaca

25

Min far sa: När vi ger efter förmåga och fär efter behov 
Min mor sa: När vi ger efter förmåga och fär efter behov

Min bror sa: När alla orättvisor och historien själv tar slut

Min mormor sa: När du är lika gammal som jag

Då ska alla orättvisor och historien själv ta slut

Meu pai disse: Quando oferecermos de acordo com o que pudermos e recebermos de acordo com o necessário

Minha mãe disse: Quando oferecermos de acordo com o que pudermos e recebermos de acordo com o necessário

Meu irmão disse: Quando todas as injustiças e a própria história chegarem ao fim

A mãe de minha mãe disse: Quando você ficar velha como eu

Aí, sim, todas as injustiças e a própria história chegarão ao fim

26

Min far sa: Begrav mig inte här

Begrav mig där all egendom exproprierats

Ge mig ingen gravsten, tillägna mig dina sötebrödsdagar

Meu pai disse: Não me enterre aqui

Enterre-me onde toda a propriedade tenha sido expropriada, numa terra sem amos

Não me dê uma lápide, dedique a mim seus dias felizes

\section{7}

Min mor sa: Det är bättre att drömma att man är död

än att dö av alla drömmar som uppfinner en

Minha mãe disse: É melhor sonhar que se está morto

Do que morrer dos sonhos que nos inventam

\section{8}

Min mormor sa: Begrav mig inte här

Begrav mig där myntan växer längs med bäckarna

Duka en festmåltid, servera min godaste gryta

A mãe de minha mãe disse: Não me enterre aqui

Enterre-me onde cresce a hortelã ao longo dos riachos

Arrume u'a mesa festiva e sirva minha mais saborosa receita de guisado

\section{9}

Min morbror sa: Kriget har aldrig tagit slut

Du har bara slutat vara krigets offer 
O irmão de minha mãe disse: A guerra nunca acabou

Você só deixou de ser vítima dela

\section{0}

Min mor sa: Begrav mig inte här

Begrav mig där civilisationens fernissa flagnat

Spotta ut mitt språk, ge mig mjölken tillbaka

Minha mãe disse: Não me enterre aqui

Enterre-me onde o verniz da civilização descascou

Cuspa minha língua, devolva o meu leite.

\section{Referências bibliográficas}

SAID, Edward. Reflexões sobre o exílio e outros ensaios. Trad. Pedro Maia Soares. São Paulo: Companhia das Letras, 2003.

CANCLINI, Néstor García. Culturas híbridas. Trad. Ana Regina Lessa e Heloísa Pezza Cintrão. São Paulo: Edusp, 2008.

https://www.aftonbladet.se/kultur/bokrecensioner/a/1kWGjB/hans-raseri-hyllas-av-danska-rasister 